九州大学学術情報リポジトリ

Kyushu University Institutional Repository

\title{
SUPPLEMENTARY NOTES ON THE GENUS PLATYCHEIRUS OF JAPAN (DIPTERA, SYRPHIDAE)
}

Ohara, Kenji

https://doi.org/10.5109/2455

出版情報: ESAKIA. 22，pp.95-102，1984-11-20. Entomological Laboratory，Faculty of Agriculture， Kyushu University

バージョン :

権利関係 : 


\title{
SUPPLEMENTARY NOTES ON THE GENUS PLATYCHEIRUS OF JAPAN (DIPTERA，SYRPHIDAE)*
}

\author{
KEN эI ÔHARA \\ Entomological Laboratory, Faculty of Agriculture, \\ Kyushu University, Fukuoka 812, Japan
}

\begin{abstract}
Two species of the genus Platycheirus, I? ovalis Becker and P. angustatus (Zetterstedt), are redescribed. P.ovalis Becker is recorded from Japan for the first time. P. subcomplicatus Ôhara, 1980 and Melanostoma alpinum Shiraki et Edashige, 1953 are synonymized with P. latimanus (Wahlberg, 1844) and P. urakawensis (Matsumura, 1919), respectively.
\end{abstract}

In my previous paper (Ôhara, 1980) I recorded 11 species of the genus Platycheirus, including 3 new species, from Japan. Since then, I have examined 2 additional species from Japan : one is $P$. ovalis Becker which is hitherto unknown from Japan, and the other is $P$. angustatus (Zetterstedt) which was already recorded from Hokkaido (Kimura, 1971), but I overlooked the record of it. Also I was able to examine the type-specimen of Melanostoma japonicum van der Goot (=M. alpinum Shiraki et Edashige) and a European specimen of $P$. Zatimanus (Wahlberg). As a result, I came to the conclusion that Melanostoma japonicum van der Goot and P. subcomplicatus Ôhara are conspecific with $P$. urakawensis (Matsumura) and P. Zatimanus (Wahlberg), *respectively.

As a supplemental study to my previous work, P. ovalis and P. angustatus are redescribed, and synonymic notes on P. subcomplicatus Ôhara and Melanostoma japonicum van der Goot are given in this paper.

Before going further, I wish to express my hearty thanks to Prof. Y. Hirashima and Assoc. Prof. K. Morimoto of the Entomological Laboratory, Kyushu University for their constant guidances and encouragements. I am much indebted to Prof. T. Saigusa and Assoc. Prof. H. Shima of the Biological Laboratory, College of General Education, Kyushu University for their critical reading of the manuscript. My cordial thanks are due to Dr. T. R. Nielsen, Norway for his kindness in offering me valuable advices and European materials, to Prof. T. Ishihara and Dr. M. Miyatake of the Entomological Laboratory, Ehime University for their kind permission to examine

* Contribution from the Entomological Laboratory, Faculty of Agriculture, Kyushu University, Fukuoka (Ser. 3, No. 158). 
K. ÔHARA

specimens in the collection of Ehime University, and to Dr. T. Kimura, Kyoto City, and Mr. T. Gotô, Entomological Laboratory, Kyushu University for their kindness in' offering me valuable materials and informations.

\section{Platycheirus ovalis Becker}

Platychims ovalis Becker, 1921. Mitt. Zool. Mus. Berlin, $10: 27$.

Platycheirus ovalis : Dušek \& Láska, 1970. Acta ent. bohemoslov., 67 : 192.

Platychims ovalis: Shtakerberg, 1970. Izdat. Nauka, 55(2): 21.

Platychims ovalis: Peck, 1977. Ins. Mongolia, 5 : 702.

Male : Head black in ground colour ; frons and face greyish brown pollinose ; ocellar tubercle and occiput densely greyish brown pollinose ; lunula, central knob, epistoma and cheek shining black; 1 st and 2nd segments of antenna black, 3rd segment brown, ventral surface of 3rd segment brownish yellow ; arista black. Hairs on ocellar tubercle, frons and face brown to black, mixed with several yellowish hairs on lower part of face ; occipital hairs dark brown to black above, yellowish brown to pale yellow below. Lunula not produced ; central knob and epistoma moderately produced ; face with a weak median carina above central knob. Third segment of antenna longer than wide, shorter than 1 st and 2 nd segments together ; arista thickened on basal $1 / 2$.

Thorax black in ground colour ; mesonotum and scutellum brownish pollinose ; pleura greyish brown pollinose. Hairs on mesonotum and scutellum almost black, mixed with yellowish ones, curled at apices ; mesopleural hairs yellowish, mixed with black ones, strongly curled at apices.

Wing hyaline, slightly tinged with brown. Veins brown to dark brown, stigma brownish yellow ; squama and its fringe brownish yellow; wing membrane entirely trichose. Halter pale brown.

Legs blackish; all coxae and trochanters black, greyish brown pollinose. All femora black, brownish yellow at apical $1 / 6-1 / 5$. Front tibia brownish yellow, apical $2 / 3$ of posterodorsal surface brown to black except tip ; ventral surface of the tibia with a narrow oblique pale yellow band at middle ; brownish area of ventral surface extending from this band to anterodistal corner along anterior surface, and with narrow subapical brown band, apical border darkened and bearing comb of setulae. Dorsal surfaces of 1st and 2nd tarsomeres of front tarsus yellowish white on basal $1 / 2$, brownish yellow on apical $1 / 2$; those of 4 th and 5th tarsomeres yellowish brown to brown. Anterior $1 / 2$ of ventral surface of 1 st tarsomere of front tarsus darkened, with a narrow yellowish white transverse band which arises from anterior subapical margin and extends near the middle of the tarsomere, posterior $1 / 2$ of the surface whitish yellow, darkened on subapical $1 / 4-1 / 3$, and with a median subapical small brown spot and 2 short narrow brownish bands apically. Ventral surface of 2 nd tarsomere of front tarsus whitish yellow, apical border and median line brownish yellow ; 3rd tarsomere pale yellow on basal $1 / 2$, brownish yellow on apical $1 / 2$; 3rd to 5th tarsomeres each with 2 basal black dots. Middle femur blackish brown, apical 1/4-1/3 

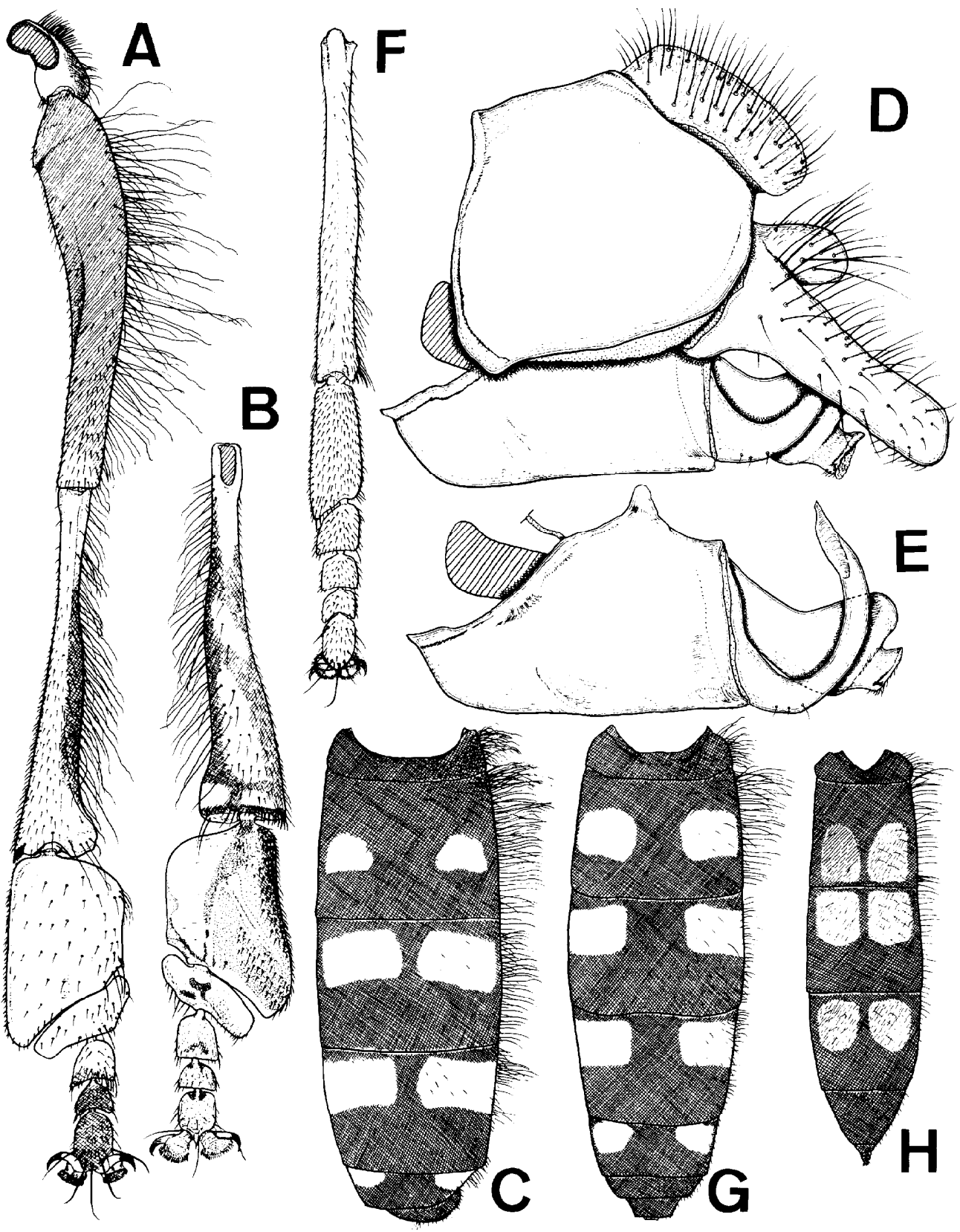

Fig. 1. Platycheirus ovalis and P. angustatus. - A-G, P. ovalis; H. P. angustatus. A, male left front leg in dorsal view ; $\mathrm{B}$, same (tibia and tarsus) in ventral view; $\mathrm{C}$, male abdomen in dorsal view ; $\mathrm{D}$, whole male genitalia in lateral view ; E, same (hypandrium, superior lobe and aedeagus) in lateral view ; F. female left front tibia and tarsus in dorsal view ; $\mathrm{G}$, female abdomen in dorsal view ; $\mathrm{H}$, female abdomen in dorsal view. 
brownish yellow except for ventral surface. Middle tibia dark brown, basal $1 / 2$ paler than apical $1 / 2$. First to 3rd tarsomeres of middle tarsus brownish yellow, 4th and 5 th tarsomeres brownish ; 3rd to 5th tarsomeres each with 2 basal black dots. Hind leg black except yellowish knee ; hind coxa greyish brown pollinose.

Front trochanter with many short black hairs on ventral surface. Front femur clothed with apically curled longish black hairs on posterior surface, ventral surface of the femur clothed with black hairs on basal $1 / 2$. Front tibia flattened and dilated on apical $1 / 5$, straight on anterior margin, weakly emarginate on apical $1 / 2$ of posterior margin ; posterior surface of the tibia clothed with short black hairs on basal $2 / 3$, short yellow hairs on apical $1 / 3$, some of these hairs recurrent ; anterior, anterodorsal and anteroventral surfaces short haired, tip of the tibia about $2.5 \mathbf{x}$ as wide as its base. First tarsomere of front tarsus remarkably large, flattened and dilated, about $1.6 \mathrm{x}$ as long as wide, and as long as 2nd to 5th tarsomeres together, strongly produced anterodistally. Second tarsomere of front tarsus short and broad, about $1 / 4 \times$ as long as $1 \mathrm{st}$, and $0.8-0.9 \mathrm{x}$ as wide as $1 \mathrm{st}$; 3rd tarsomere $1.5 \times$ as long as 4 th, 4th and 5th tarsomeres normal in shape. Middle femur clothed with longish black hairs on basal $1 / 2$ of anterior, ventral and posterior surfaces, mixed with yellowish hairs, apical $1 / 4$ of anterior surface with recurrent black hairs, dorsal surface short yellow haired. Middle tibia weakly curved ventrally clothed with curled long black hairs on anterior, ventral and posterior surfaces; dorsal surface clothed with rather short black hairs. Middle tarsus short brownish yellow haired. Hind coxa clothed with curled long yellow hairs on anterior surface. Hind trochanter with several yellow hairs on ventral surf ace. Hind femur sparsely clothed with long yellow hairs on anterior and ventral surfaces ; dorsal surface of the femur with short black hairs on apical $1 / 2$, posterior surface of the femur short yellow haired. Hind tibia clothed with short yellow hairs on anteroventral, ventral and posteroventral surfaces, mixed with slightly longer black hairs at the middle of the ventral surface ; anterodorsal surface with a row of several longish black hairs on middle 1/3. First tarsomere of hind tarsus remarkably thickened, and about as long as 2nd to 5th tarsomeres together.

Abdomen black in ground colour, brown pollinose ; 2nd to 5th terga each with a pair of lateral brownish yellow spots ; those on 2nd tergum small, situated near middle, $1 / 4 \times$ as long as the tergum ; those on $3 \mathrm{rd}$ and 4 th terga subquadrate in shape, close to narrow black anterior margin, about $1 / 3 \times$ as long as each tergum ; those on 5 th tergum small, triangular in shape. Abdominal terga clothed with short hairs which are almostly following the ground colour.

Male genitalia : Similar to those of P.peltatus (Meigen). Surstylus short, subparallel. Hypandrium weakly excavated on posterolateral 1/3. Superior lobe separated from hypandrium by a slender membraneous area, without a dorsoproximal projection. Aedeagus slender on basal $1 / 2$, its dorsal swelling strong.

Length : Body 9.5-11.0 mm ; wing 9.5-9.7 mm.

Female : Similar to male. Head black ; frons shining black with a pair of large triangular grey pollinose markings at middle ; lunula shining black ; face grey pollinose, shining on central knob, epistoma and cheek ; occiput densely greyish white 
pollinose. Hairs on frons black, those on face blackish above, yellowish below ; occipital hairs white to whitish yellow, a few black hairs mixed on dorsal portion of occiput. Central knob and epistoma moderately produced. Lunula with a shallow longitudinal furrow at the middle. Antenna and arista almost as in male.

Thorax almost as in male ; mesopleural hairs whitish yellow, curled at apices ; wing hyaline, slightly tinged with brown, membrane entirely trichose.

Legs almost brown to black with following areas brownish yellow : Base and apical $1 / 3$ of front femur, basal $1 / 3$ of front tibia, base and apical $1 / 3$ of middle femur, basal $1 / 2$ of middle tibia, 1st to 3rd tarsomeres of middle tarsus, base and tip of hind femur, base of hind tibia.

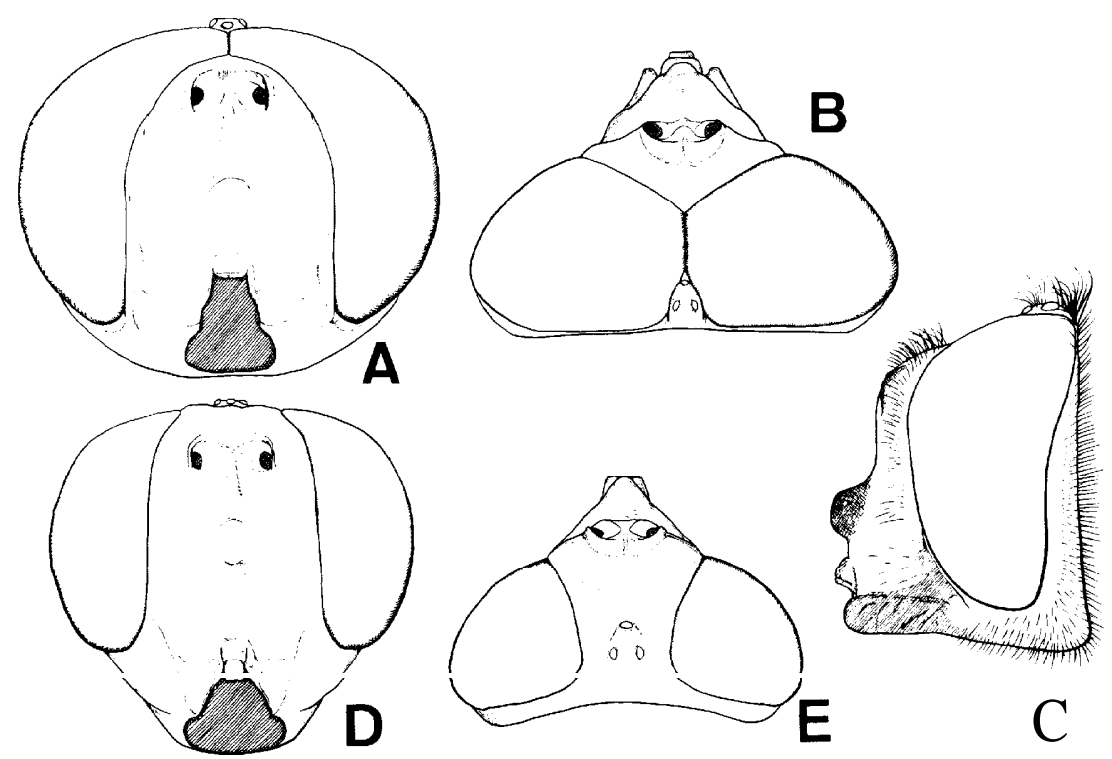

Fig. 2. Head of Platycheirus ovalis. - A-C, male ; D, E, female. A, D, frontal view ; B, E, dorsal view ; C, lateral view.

Front coxa and trochanter with short yellow hairs on ventral surface. Front femur clothed with longish yellow hairs on posterior surface, dorsal and anterior surfaces short yellow haired. Front tibia with short yellow hairs, posterodorsal hairs slightly longer than others. Front tarsus short yellow haired, 1st tarsomere slightly dilated and flattened, $3 \mathrm{X}$ as long as and about $1.3 \mathrm{X}$ as wide as 2nd tarsomere ; 2nd tarsomere slightly dilated and flattened, about $1.3 \times$ as long as 3rd tarsomere, and about $1.2 \mathrm{X}$ as wide as $3 \mathrm{rd}$; 3rd to 5th tarsomeres normal in shape. Middle femur clothed with long yellow hairs on base $1 / 2$, and with long black ones on apical $1 / 2$ of posterior surface ; other part of the middle leg short yellow haired. Hind leg short yellow haired, anterior surface of femur sparsely clothed with long yellow hairs ; 1st 
tarsomere of hind tarsus more strongly thickened than the tip of hind tibia, and as long as 2nd to 5th tarsomeres together.

Abdomen almost as in male, but slightly ovate. Abdominal spots almost as in male, but those on 1st and 5th terga longer than in male.

Length : Body 10.4-10.7 mm ; wing 9.4-9.6 mm.

Distribution : This species has hitherto been known from Europe, Ural and Mongolia. In Japan it was collected at the alpine region of Honshu for the first time.

Specimens exAmined : (HONSHU) $30^{\top} 0^{\top} 2$ 우, Mt. Kita-dake (3,000 m), Ashiyasumura, Yamanashi Pref., 21. vii. 1981, Tadao Got8 leg.

Remarks: This species appears to be allied to Platycheirus manicatus (Meigen), $P$. himalayensis Brunetti and P.peltatus (Meigen) in the structure of the male genitalia and male front legs. This species is likely to be confused with peltatus (so far as Japanese species are concerned) from which, however, it may be easily distinguished in the male by absence of the characteristic anterior excavation of the middle femur, absence of the ventral excavation of the middle tibia, and the shape of the 1st and 2nd tarsomeres of the front tarsus,

\section{Platycheirus latimanus (Wahlberg)}

Scaeva latimanus Wahlberg, 1844. Öfvers. Kongl. Vet. Akad. Förhandl., 1 : 66.

Platychirus latimanus : Sack, 1930. Die Fliegen, 31. Syrphidae. p. 149.

Platychirus latimanus : Shtakerberg, 1970. Izdat. Nauka, 5(2):21.

Platycheirus subcomplicatus Ôhara, 1980. Esakia, (15) : 120. New synonymy.

Platycheirus latimanus : Nielsen, 1981. Ent. scand., 12: 100.

Dr. Tore R. Nielsen (Norway) kindly called my attention to the similarity of Japanese P.subcomplicatus Ôhara, 1980, and European P.latimanus (Wahlberg) which was originally described from Sweden. He kindly sent me one male of latimanus from Norway. Although the abdominal marking and colouration of legs are slightly variable, I failed to find any significant difference, especially in the shape of the front legs and male genitalia. Therefore I conclude that they are conspecific, so that subcomplicatus is synonymized with latimanus.

\section{Platycheirus urakawensis (Matsumura)}

Melanostoma urakawense Matsumura, 1919. Ent. Mag., Kyoto, 3(3,4): 132.

Melanostoma alpinum Shiraki et Edashige, 1953. Trans. Shikoku ent. Soc., 3(5,6): 96. New synonymy.

Platycheinus urakawensis: Minamikawa \& Fukuhara, 1964. Kontyû, 32(2): 225.

Melanostoma japonicum van der Goot, 1964. Beaufortia, 10 :218. (new name for Melanostoma alpinum Shiraki et Edashige, 1953 nec Melanostoma alpinum Szilady, 1942). New synonymy.

Shiraki and Edashige (1953) described Melanostoma alpinum on the basis of 8 females from Mt. Ishizuchi, Ehime Pref., Shikoku, Japan, which was renamed as japonicum by van der Goot, because the specific name was preoccupied by Szilady, 1942. 
Recently I have examined the female holotype of Melanostomaalpinum Shiraki et Edashige preserved in the collection of the Entomological Laboratory, Faculty of Agriculture, Ehime University, Matsuyama, and found that it is conspecific with Platycheirus urakawensis (Matsumura). Thus, M elanostoma japonicum van der Goot (= Melanostoma alpinum Shiraki et Edashige) is treated as a junior synonym of Platycheinus urakawensis (Matsumura, 1919).

\section{Platycheirus angustatus (Zetterstedt)}

Scaeva angustata Zetterstedt, 1843. Dipt. Scand., 2: 762.

Platychims angustatus : Verrall, 1901. Brit. Flies, $8: 295$.

Platychims angustatus: Sack, 1930. Die Fliegen, 31. Syrphidae. p. 145.

Platychims angustatus : Violovitsh, 1960. Horae Soc. Ent. Unionis Sovieticae, 47 : 230.

Platychims angustatus : Shtakerberg, 1970. Izdat. Nauka, 5(2): 22.

Platycheirus angustatus : Kimura, 1971. Nature and Insects, 6(3): 9.

Female : Head black; frons shining black with a pair of large triangular grey pollinose markings at middle; face grey pollinose, subshining on central knob and epistoma. Hairs on frons and face yellow, those on ocellar tubercle brownish yellow ; those on occiput yellowish above, whitish below. Lunula, central knob and epistoma weakly produced. Antenna brown, 3rd segment longer than wide and as long as 1 st and 2nd segments together, arista brown, thickened on basal $1 / 3$.

Thorax black; mesonotum and scutellum subshining black; pleura grey pollinose. Hairs on mesonotum and scutellum yellow and straight ; those on mesopleuron yellow, curled at apices.

Legs brownish yellow with following areas brown : All coxae and trochanters, middle $1 / 2$ of hind femur, middle $1 / 3$ of hind tibia, 1st, 4th and 5th tarsomeres of hind tarsus except base and tip of 1 st tarsomere.

Front femur with a small posterior tuft of 2-3 silky white hairs near base, and with a irregular ventral row of longish yellow and brownish yellow hairs ; other part of the femur short yellow haired. Front tibia gradually dilated from base to tip, tip of the tibia $1.5 \times$ as wide as base. Front tarsus short yellow haired ; 1st tarsomere slightly dilated and flattened, $2.4 \times$ as long as wide and as long as 2nd to 4th tarsomeres together ; 2nd tarsomere as wide as and $0.4 \times$ as long as 1st ; 3rd to 5th tarsomeres normal in shape. Middle femur with irregular posterior rows of long yellow hairs of which middle to subapical ones are black, other parts of the femur sparsely clothed with short yellow hairs. Middle tibia and tarsus short yellow haired. Hind femur clothed with short yellow hairs. Hind tibia short yellow haired ; apical $1 / 5$ of the tibia thickened, tip of the tibia about $2 \times$ as wide as base. Hind tarsus short brown haired on dorsal surface, short yellow haired on ventral surface ; 1st tarsomere slightly thickened and as thick as the tip of hind tibia.

Wing hyaline, slightly tinged with brownish yellow. Veins brown; stigma brownish yellow; squama and its fringe pale brownish yellow. Halter brownish yellow. 
Abdomen black in ground colour, thinly grey pollinose, 2nd to 4th terga each with a pair of lateral dull orange yellow spots, those on 2nd tergum extending from the middle to posterior submargin of tergum; those on 3rd tergum large and subquadrate in shape, and extending from anterior submargin beyond the middle ; those on 4th tergum small and obscure, circular in shape, situated on anterior portion. Abdominal terga clothed with short yellowish white hairs, lateral hairs longer than dorsal ones, hairs on 1st tergum longest and slightly curled at apices. Abdominal sterna pale brown, short pale yellow haired.

Length : Body 7.6-8.0 mm ; wing 6.3-6.5 mm.

Male: Unknown to me.

Distribution : This species has been known from Europe, Mongolia, Sakhalin, North America and Japan (Hokkaido).

SpeCimens eXAMined: (HOKKAIDO) 1 1 , Ginmeisui, Mt. Rausu-dake, Shari-cho, 4. viii. 1967, T. Saigusa leg. ; 1 옹 Toro-ko, Shibecha-cho, Kushiro, 26. viii. 1979, K. Ôhara leg.

Remarks : This species has been recorded from the Rishiri Island, Hokkaido, based on a male specimen by Kimura in 1971, but I overlooked this record in my previous paper (Ôhara, 1980). This species appears to be allied to P.perpallidus Verrall and P.clypeatus (Meigen), but the shape of the abdomen and abdominal markings of the female are markedly different.

\section{References}

Dušek, J. and P. Láska, 1970. Platycheinus ovalis Becker, A redescription of the male and first description of the female (Diptera, Syrphidae). Acta ent. bohemoslov., $67: 1922197$.

Goot, V. S. van der, 1964. Fluke's catalogue of neotropical Syrphidae (Insecta, Diptera), a critical study with an appendix on new names in Syrphidae. Beaufortia, 10(127): 212-221.

Kimura, T., 1971. "Two species of syrphid flies collected from the Rishiri Island". Nature and Insects, 6(3) : 8-9. (In Japanese)

Matsumura, S. and J. Adachi, 1919. Synopsis of the economic Syrphidae of Japan (IV). Ent.Mag., Kyoto, $3(3,4): 128-144$.

Minamikawa, J. and N. Fukuhara, 1964. On the syrphid larvae attacking the aphid, Myzus persicae Sulzer. Kontyû, Tokyo, $32: 225$. (In Japanese)

Nielsen, T. R., 1981. Studies on Platycheirus Lepeletier \& Serville: $P$. complicatus Becker, $P$. latimanus (Wahlberg) and P. boreomontanus nom. nov. (Diptera, Syrphidae). Ent. scand., 12 :99102.

Ôhara, K., 1980. The genus Platycheirus Lepeletier and Serville, 1828 (Diptera, Syrphidae) of Japan, with descriptions of three new species. Esakia, (15) : 97-142.

Sack, P., 1932. Syrphidae, in Lindner "Die Fliegen der palaearkt. Reg.“, 31: 1-451.

Shiraki, T. and T. Edashige, 1953. The insect fauna of Mt. Ishizuchi and Omogo Valley, Iyo, Japan : The Syrphidae (Diptera). Trans. Shikoku ent. Soc.,3(5, 6) : 84-125.

Verrall, G. H., 1901. Syrphidae, British Flies, 8 : pp. 691.

Violovitsh, N. A., 1960. A contribution to the knowledge of the hover flies fauna (Diptera, Syrphidae) of Sachalin and Kuril isls. Horae Soc. ent. Uni. Sov., $47: 212-272$. (In Russian) 